Management and Business Review, 1(2) 2017, 87-95

\begin{tabular}{c|c}
\hline MIBR & \begin{tabular}{c} 
Management and Business Review \\
Available at http://ejournal. 1nikama.ac.id/index.php/mbr \\
MANAGEMENT \& $2541-5808$ (online) \\
\hline
\end{tabular} \\
\hline
\end{tabular}

\title{
Pengaruh lingkungan kerja dan motivasi kerja terhadap kepuasan kerja karyawan
}

\author{
Ririn Puji Astutik \\ Program Studi Manajemen, Fakultas Ekonomika dan Bisnis, Universitas Kanjuruhan Malang, \\ Indonesia \\ e-mail: pujiririn601@gmail.com
}

\begin{tabular}{ll}
\hline \multicolumn{2}{l}{ Article Info: } \\
Receive $\quad$ : Mei 2017 \\
Revised & $:$ Juni 2017 \\
Accepted & $:$ Juni 2017 \\
Published & $:$ Juni 2017 \\
DOI & $:$ 10.21067/mbr.v1i2.4728 \\
Copyright & $:$ Management and \\
& Business Review
\end{tabular}

Keywords :

working environment, job motivation, job satisfaction

\begin{abstract}
The purpose of this study was to analyze the influence of the working environment and job motivation simultaneously or partially on employee job satisfaction. This research method uses a quantitative approach aims to determine the effect of two or more variables. The population in this study were 79 respondents, as a saturated sample. The data collection is done by distributing questionnaires. Variables used in this study is the work environment and work motivation and job satisfaction of employees at PT PLN (persero) Distribution area of Malang, East Java. Data analysis technique used is Multiple Regression. The results of this study stated that the work environment and work motivation have a significant effect on employee job satisfaction. The better the work environment and work motivation the better the job satisfaction of employees.
\end{abstract}

Abstrak: Tujuan penelitian ini adalah untuk menganalisis pengaruh lingkungan kerja dan motivasi secara terhadap kepuasan kerja karyawan. Metode penelitian ini menggunakan pendekatan kuantitatif dengan metode survey bertujuan untuk mengetahui pengaruh antara dua variabel atau lebih. Populasi dalam penelitian ini sebanyak 79 responden yaitu sebagai sampel jenuh. Pengumpulan data dilakukan dengan menyebarkan kuesioner. Variabel penelitian yang digunakan yaitu lingkungan kerja dan motivasi kerja dan kepuasan kerja karyawan di PT PLN (persero) Distribusi jawa timur area Malang. Teknik analisis data yang digunakan adalah Regresi Berganda. Hasil penelitian ini menunjukkan bahwa lingkungan kerja dan motivasi kerja berpengaruh signifikan terhadap kepuasan kerja karyawan. Semakin baik lingkungan kerja dan motivasi kerja maka semakin baik pula kepuasan kerja karyawan. 


\section{Pendahuluan}

Keberhasilan suatu organisasi merupakan hal yang sangat penting, dalam hal ini karyawan diharapkan dapat memberikan hasil yang maksimal sehingga tujuan dari perusahaan atau organisasi dapat tercapai. Kepuasan kerja merupakan salah satu faktor bagi karyawan agar dapat bekerja secara maksimal. Dawal \& Taha (2006) menyatakan bahwa kepuasan kerja bagi karyawan merupakan kunci dari sehatnya sebuah organisasi. Kepuasan kerja karyawan adalah keadaan emosional karyawan dimana terjadi titik temu antara balas jasa karyawan dari organisasi atau perusahaan dengan nilai tingkat balas jasa yang memang diinginkan oleh karyawan yang bersangkutan.

Bila kepuasan karyawan terjadi, maka pada umumnya tercermin pada perasaan karyawan terhadap perusahaanya, yang sering diwujudkan dalam sikap positif karyawan terhadap pekerjaan, terhadap sesuatu yang dihadapi atau ditugaskan kepadanya dilingkungan kerjanya (Martoyo, 2007). Sudiarditha et al. (2016) menyatakan bahwa semakin puas karyawan terhadap perusahaan, akan semakin tinggi pula motivasi mereka dalam menjalankan segala pekerjaanya. Fasilitas kerja yang diberikan juga berhubungan langsung terhadap lingkungan kerja karyawan. Lingkungan kerja di perusahaan berhubungan dengan kepuasan karyawan serta hasil yang akan didapat oleh perusahaan. Jika lingkungan kerja nyaman, hal ini akan membantu setiap karyawan dalam menyelesaikan pekerjaannya, dan memberikan kepuasan tersendiri bagi setiap karyawan.

Kondisi lingkungan kerja mempunyai peranan penting terhadap baik buruknya kualitas dari hasil kinerja karyawan. Bila lingkungan kerja nyaman serta baik dan komunikasi di dalamnya berjalan dengan lancar, maka kinerja yang dihasilkan pun tentu akan maksimal. Namun sebaliknya, apabila lingkungan kerja tidak nyaman, dipenuhi dengan kekacauan dan persaingan tidak sehat, maka akan tercipta kejenuhan dari para karyawan yang pada akhirnya akan menurunkan motivasi kerja mereka dan menciptakan ketidakpuasan dalam bekerja dan karyawan tidak bergairah atau bersemangat dalam melaksanakan pekerjaanya.

Hal tersebut didukung dari penelitian Susetyo et al. (2014) yang mengatakan adanya pengaruh positif pada lingkungan kerja karyawan terhadap kepuasan kerja karyawan di PT Bank Muamalat Indonesia Area Cabang Surabaya. Timbulnya motivasi kerja dipengaruhi oleh beberapa faktor pendorong, baik dari dalam maupun luar individu karyawan itu sendiri. Hoy \& Miskel (1987) menyatakan bahwa dorongan (motivasi) untuk melakukan atau mengerjakan sesuatu dapat bersifat ekstrinsik aupun intrinsik. Dorongan intrinsik merupakan dorongan yang timbul dari dalam diri seseorang dan mengarah pada objek tertentu untuk melakukan atau berbuat dan berperilaku. Sementara dorongan ekstrinsik merupakan akibat rangsangan-rangsangan dari luar (eksternal) yaitu faktor organisasi dan kepemimpinan, dimana kedua dorongan tersebut dapat berjalan sendiri-sendiri atau bersamaan. Menurut Hasibuan (2003) motivasi merupakan 
pemberian daya penggerak yang menciptakan gairah kerja seseorang agar mereka mau bekerja sama, bekerja efektif, dan berintegrasi dengan segala daya upaya nya untuk mencapai kepuasan yang diinginkan. Hal ini dibuktikan dengan penelitian dari Brahmasari \& Suprayetno (2008) yang mengatakan bahwa ada pengaruh positif dan signifikan pada variabel motivasi kerja terhadap kepuasan kerja karyawan. Untuk itu tujuan penelitian ini yaitu menganalisis pengaruh lingkungan kerja dan motivasi secara simultan ataupun parsial terhadap kepuasan kerja karyawan. Tujuan penelitian ini adalah untuk menganalisis pengaruh lingkungan kerja terhadap kepuasan kerja karyawan di PT PLN (Persero) Distribusi Jawa Timur Area Malang, pengaruh Motivasi kerja terhadap kepuasan kerja karyawan di PT PLN (Persero) Distribusi Jawa Timur Area Malang.

\section{Hubungan antara lingkungan kerja terhadap kepuasan kerja}

Lingkungan Kerja menurut Sedarmayanti (2009) keseluruhan alat perkakas dan bahan yang dihadapi, lingkungan sekitarnya dimana seseorang bekerja, metode kerjanya, serta pengaturan kerjanya baik sebagai perseorangan maupun sebagai kelompok, lingkungan kerja terbagi atas dua macam yaitu lingkungan kerja fisik dan lingkungan kerja non fisik. Lingkungan kerja fisik adalah semua keadaan yang berbentuk fisik yang terdapat disekitar tempat kerja yang dapat mempengaruhi pegawai baik secara langsung maupun tidak langsung. Lingkungan kerja non fisik adalah semua keadaan yang terjadi yang berkaitan dengan hubungan kerja dengan atasan maupun hubungan sesama rekan kerja. Menciptakan lingkungan yang kondusif memang tidak mudah, hal ini perlu diperhatikan para pimpinan perusahaan, mengingat kondisi lingkungan kerja yang kondusif mendorong tiap anggota di dalamnya untuk menyelesaikan tugas mereka dengan baik yang nantinya berdampak pada kepuasan kerja karyawan. Hal tersebut didukung dengan Penelitian Paramita et al. (2013) menunjukkan bahwa ada pengaruh positif lingkungan kerja terhadap kepuasan kerja. Serta penelitian oleh Salunke (2015) yang menyatakan adanya pengaruh lingkungan kerja terhadap kepuasan kerja di pabrik gula koperasi Maharashtra. Oleh karena itu penting untuk menjaga agar karyawan tetap merasa nyaman dalam bekerja didukung dengan keadaan maupun situasi yang baik yang ada disekitar lingkungan kerja karyawan. Lingkungan kerja yang meliputi hubungan kerja yang harmonis, target yang jelas, iklim kerja yang dinamis, fasilitas kerja yang tercukupi dapat mempengaruhi kepuasa kerja karyawan.

\section{Hubungan antara motivasi kerja terhadap kepuasan kerja}

Motivasi mendorong karyawan untuk bekerja secara efektif dan efesien yang berbeda antar karyawan satu dengan yang lain. Perbedaan ini disebabkan oleh perbedaan motivasi, tujuan, dan kebutuhan dari masing-masing karyawan untuk bekerja, dan juga dikarenakan oleh perbedaan waktu dan tempat. Motivasi Abraham Maslow (Sule \& Saefullah, 2005) membagi kebutuhan manusia, yang 
paling mendasar yaitu kebutuhan Fisik seperti rasa lapar, rasa haus, dan sebagainya, kebutuhan rasa Aman, kebutuhan Sosial, kebutuhan akan Penghargaan, dan Aktualisasi diri.

Pemenuhan kebutuhan tersebut merupakan dasar dari motivasi kerja seorang karyawan. Jika dalam proses pemenuhan kebutuhan tersebut karyawan merasakan adanya peluang dalam mencapai tujuannya, maka motivasi untuk mencapainya akan makin berlipat. Saat tujuannya tercapai, yakni pemenuhan kebutuhan, seseorang karyawan akan merasakan kepuasan dari aktivitasnya untuk memenuhi kebutuhan tersebut. Didukung dengan penelitian oleh Saleem et al. (2010) yang menyatakan adanya pengaruh signifikansi antara variabel motivasi kerja terhadap kepuasan kerja. Penelitian Rozzaid et al. (2015) menunjukkan bahwa pengaruh kompensasi terhadap kepuasan kerja. Motivasi sangat perpengaruh penting bagi perusahaan karyawan akan mengekspresikan rasa senang dengan pekerjaanya melalui prestasi yang dicapai oleh karyawan dan berdampak baik bagi perusahaan untuk kedepannya.

\section{Hubungan antara lingkungan kerja dan Motivasi kerja terhadap kepuasan kerja}

Perusahaan diharapkan dapat memberikan yang terbaik untuk para karyawannya karena setiap karyawan akan merasa puas apabila seluruh kebutuhan yang mereka harapkan terpenuhi. Individu yang merasa puas terhadap apa yang telah didapatkannya akan cenderung memberikan timbal balik yang sesuai dengan apa yang didapatkan, seperti memberikan waktu dan tenaganya untuk suatu perusahaan, dan memiliki motivasi yang tinggi untuk menghasilkan sesuatu yang terbaik.

Berdasarkan penjelasan di atas, didukung pula dengan penelitian Sudiarditha et al. (2016) yang menyatakan bahwa lingkungan kerja dan motivasi kerja secara bersama-sama memiliki pengaruh yang signifikan terhadap kepuasan kerja. Dari penelitian tersebut menjelaskan bahwa lingkungan kerja dan motivasi kerja mempunyai peranan penting bagi perusahaan terutama berdanpak pada kepuasan karyawan dalam bekerja.

\section{Metode}

Metode penelitian ini menggunakan pendekatan kuantitatif yang menjelaskan pengaruh variabel-variabel yang diteliti terkait dengan lingkungan kerja dan motivasi kerja terhadap kepuasan kerja karyawan di PT PLN (persero) Distribusi Jawa Timur Area Malang. Populasi yang digunakan sebanyak 79 responden, teknik pengambilan sampel yaitu seluruh karyawan tetap di PT PLN (persero) Distribusi Jawa Timur Area Malang

Teknik pengumpulan data menggunakan Kuesioner yang dibagikan kepada responden, kuesioner disusun dalam Skala Likert 5 pilihan jawaban. Kuesioner sebelum digunakan telah diuji validitas dan reliabilitasnya. Teknik analisis data 
menggunakan Regresi Linier Berganda digunakan untuk menganalisis hubungan kausal dua variabel bebas atau lebih secara bersama-sama dengan satu variabel terikat.

\section{Hasil}

Berdasarkan deskripsi profil responden, menginformasikan bahwa jumlah responden dari total sebanyak 79 responden meliputi 39 perempuan (49,37\%), 39 laki-laki (49,37\%). Berdasarkan Masa Kerja sebanyak 27 responden (34,18\%) dengan masa kerja 6-10 tahun, sedangkan yang paling sedikit 4 responden (5,06\%) dengan masa kerja 26-30 tahun. Dari sisi usia, di dominasi dengan jumlah 19 responden (24,05\%) berusia $26-30$ tahun, yang paling sedikit yaitu 1 responden $(1,27 \%)$ berusia 56-60 tahun. Berdasarkan pendidikan, 35 responden $(44,30 \%)$ berpendidikan S1, Sedangkan yang paling sedikit yaitu sebanyak 1 responden $(1,27 \%)$ pendidikan SMK. Berdasarkan jabatan 24 responden (30,38\%) memiliki jabatan di bagian jaringan, Sedangkan yang paling sedikit yaitu 1 responden $(1,27 \%)$ yang memiliki jabatan manajer.

\section{Analisis Regresi Berganda}

Analisis regresi linier berganda digunakan untuk mengetahui seberapa besar pengaruh variabel bebas Lingkungan Kerja (X1) dan Motivasi Kerja (X2) terhadap Kepuasan Kerja (Y), disajikan pada tabel 1. Hasil analisis diperoleh nilai koefisien regresi lingkungan kerja sebesar 0,300 menunjukkan bahwa lingkungan kerja memiliki pengaruh positif (searah) terhadap kepuasan kerja, artinya kenaikan lingkungan kerja akan menyebabkan kepuasan kerja (Y) meningkat dan sebaliknya.

Tabel 1

Rekapitulasi Hasil Analisis Regresi Berganda

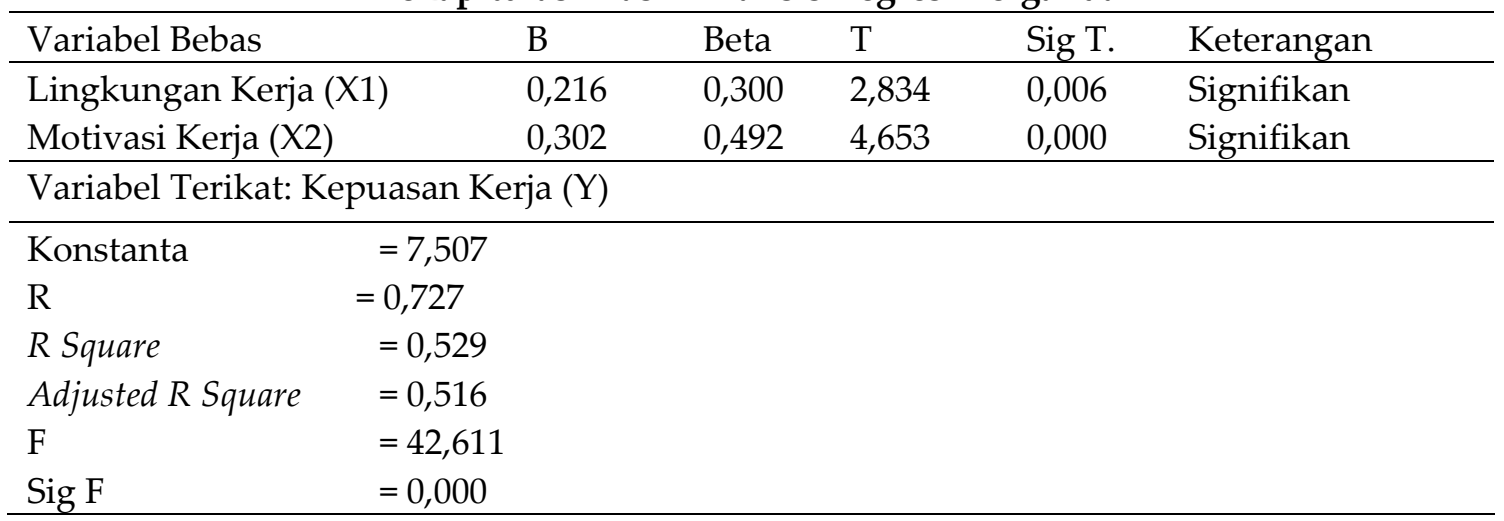

Sumber : Data Diolah, 2017

Koefisien regresi motivasi kerja sebesar 0,492 menunjukkan bahwa motivasi kerja memiliki pengaruh positif (searah) terhadap kepuasan kerja, artinya semakin 
meningkat motivasi kerja akan menyebabkan peningkatan kepuasan kerja sebaliknya.

Hasil analisis diperoleh nilai $\mathrm{F}$ hitung sebesar 42,611 dengan signifikan sebesar 0,000, berarti signifikan F kurang dari 0,05 menunjukkan bahwa variabel lingkungan kerja dan motivasi kerja mampu menjelaskan perubahan kepuasan kerja. Selanjutnya nilai koefisien determinasi (Adjusted Square) sebesar 0,516 artinya 51,6 \% kepuasan kerja dapat dijelaskan oleh lingkungan kerja dan motivasi kerja, sedangkan sisanya sebesar 48,4\% dipengaruhi oleh faktor-faktor lain.

\section{Uji Hipotesis}

Berdasarkan hasil analisis uji t pada tabel 1 dapat dijelaskan bahwa hasil Uji t variabel lingkungan kerja diperoleh nilai sebesar 2.834 dengan signifikansi sebesar $0,006<0,05$, berarti ada pengaruh yang signifikan dari variabel lingkungan kerja terhadap kepuasan kerja. Dengan demikian dapat disimpulkan bahwa hipotesis 1 diterima. Uji $\mathrm{t}$ variabel motivasi kerja diperoleh nilai sebesar 4.653 dengan signifikansi sebesar 0,000 $<0,05$, berarti ada pengaruh yang signifikan dari variabel motivasi kerja terhadap variabel kepuasan kerja. Dengan demikian dapat disimpulkan bahwa hipotesis 2 diterima.

\section{Pembahasan}

\section{Pengaruh Lingkungan Kerja terhadap Kepuasan Kerja}

Kepuasan kerja karyawan bisa lebih ditingkatkan lagi dengan memperhatikan lingkungan kerja baik secara fisik maupun non fisik sehingga karyawan dapat melaksanakan kegiatannya secara optimal (Sedarmayanti, 2009). Dari hasil analisis data yang dilakukan di atas, didapatkan hasil bahwa lingkungan kerja secara parsial berpengaruh terhadap kepuasan kerja karyawan di PT PLN (Persero) Distribusi Jawa Timur Area Malang. Hubungan ini bersifat positif, artinya semakin baik lingkungan kerja maka kepuasan kerja akan semakin baik pula. Hasil penelitian ini sejalan dengan penelitian yang dilakukan oleh Tampubolon (2010) yang mengidentifikasi bahwa semakin nyaman lingkungan kerja di tempat kerja maka kepuasan karyawan akan meningkat. Serta penelitian dari Riansari \& Sudiro (2012) yang menyatakan setuju bahwa lingkungan kerja berpengaruh signifikan terhadap kepuasan kerja Karyawan di PT Bank Tabungan Pensiunan Nasional. Penelitian Prastowo (2015) yang mengatakan adanya pengaruh positif pada lingkungan kerja karyawan terhadap kepuasan kerja karyawan di Hotel Sahid Jaya Solo.

Berdasarkan hasil penelitian, didapat juga bahwa karyawan PT PLN (Persero) Distribusi Jawa Timur Area Malang merasa hubungan rekan kerja masih belum terlalu baik. Hal ini perlu lebih diperhatikan oleh pimpinan perusahaan. Pimpinan perlu mengkondisikan hubungan kerja yang baik antar pegawai sehingga akan terlihat pada suasana kerja yang baik seperti: tidak adanya konflik antar pegawai, 
setiap pegawai bersemangat dan bergairah dalam menyelesaikan pekerjaan yang menjadi tugasnya, penyelesaian masalah dengan penuh kekeluargaan, suasana kerja yang santai dan keakraban, bukan suasana yang mencekam penuh ancaman, dan adanya saling menghargai dan percaya antar pegawai.

\section{Pengaruh Motivasi Kerja terhadap Kepuasan Kerja}

Kepuasan kerja karyawan bisa lebih ditingkatkan lagi dengan meningkatkan motivasi kerja karyawan, antara lain dengan memenuhi kebutuhan fisik (rasa lapar, rasa haus, dan sebagainya), kebutuhan keamanan (merasa aman dan terlindung, jauh dari bahaya), kebutuhan sosial (kebutuhan untuk persahabatan, interaksi yang lebih erat dengan orang lain), kebutuhan akan penghargaan (berprestasi, berkompetensi, dan mendapatkan dukungan serta pengakuan) dan kebutuhan aktualisasi diri (Sule \& Saefullah, 2005). Dari hasil analisis data yang dilakukan di atas, didapatkan hasil bahwa motivasi kerja secara parsial berpengaruh terhadap kepuasan kerja karyawan di PT PLN (Persero) Distribusi Jawa Timur Area Malang. Hubungan ini bersifat positif, artinya semakin baik motivasi kerja maka Kepuasan Kerja akan semakin baik pula.

Hasil penelitian ini sejalan dengan penelitian oleh Mardiono (2014) yang mengatakan bahwa ada pengaruh positif dan signifikan pada variabel motivasi kerja terhadap kepuasan kerja karyawan. Serta penelitian oleh Muslih (2012) yang menunjukkan variabel motivasi berpengaruh signifikan terhadap kepuasan kerja karyawan. Penelitian dari Priadana \& Riswandi (2013) yang setuju bahwa Motivasi memberikan dampak positif terhadap kepuasan kerja karyawan di Dinas Pertambangan dan Energi Provinsi Jawa Barat. Berdasarkan hasil penelitian, didapat juga bahwa karyawan PT PLN (Persero) Distribusi Jawa Timur Area Malang masih belum memiliki adanya rasa aman dari pemutusan hubungan kerja. Perusahaan harus memperhatikan hal ini, harus dapat memberikan jaminan kepada karyawan mengenai keamanan dari pemutusan hubungan kerja. Sehingga diharapkan motivasi kerja karyawan akan lebih meningkat, yang pada akhirnya kepuasan kerja meningkat pula.

\section{Simpulan}

Berdasarkan analisis dan pembahasan hasil pengujian hipotesis yang telah dilakukan diajukan beberapa kesimpulan penting yang merupakan inti dari hasil dalam penelitian ini yaitu berdasarkan hasil pengujian hipotesis pertama ditemukan bahwa lingkungan kerja berpengaruh signifikan terhadap kepuasan kerja karyawan di PT PLN (Persero) Distribusi Jawa Timur Area Malang, Selanjutnya berdasarkan hasil pengujian hipotesis kedua ditemukan bahwa motivasi kerja berpengaruh signifikan terhadap kepuasan kerja karyawan di PT PLN (Persero) Distribusi Jawa Timur Area Malang, kemudian berdasarkan hasil pengujian hipotesis ketiga ditemukan bahwa lingkungan kerja dan motivasi kerja secara bersama-sama 
berpengaruh signifikan terhadap kepuasan kerja karyawan di PT PLN (Persero) Distribusi Jawa Timur Area Malang.

Diharapkan bagi penelitian dimasa mendatang sebaiknya memperluas terkait judul variabel sehingga kepuasan kerja karyawan PT PLN (Persero) Distribusi Jawa Timur Area Malang bisa lebih meningkat. Serta diharapkan dapat mengkaji lebih dalam tentang motivasi kerja dan lingkungan kerja yang berpengaruh terhadap kepuasan kerja karyawan pada PT PLN (Persero) Distribusi Jawa Timur Area Malang agar diperoleh gambaran yang lebih lengkap lagi, sehingga diharapkan hasil penelitian yang akan datang lebih baik dari penelitian ini.

\section{Daftar Pustaka}

Brahmasari, I. A., \& Suprayetno, A. (2008). Pengaruh motivasi kerja, kepemimpinan dan budaya organisasi terhadap kepuasan kerja karyawan serta dampaknya pada kinerja perusahaan (Studi kasus pada PT. Pei Hai International Wiratama Indonesia). Jurnal Manajemen Dan Kewirausahaan, 10(2), 124-135.

Dawal, S. Z. M., \& Taha, Z. (2006). The effect of job and environmental factors on job satisfaction in automotive industries. International Journal of Occupational Safety and Ergonomics, 12(3), 267-280.

Hasibuan, M. S. P. (2003). Organisasi dan motivasi: dasar peningkatan produktivitas. Jakarta: Bumi Aksara.

Hoy, W. K., \& Miskel, C. G. (1987). Educational administration: Theory, research, and practice. Random House Trade.

Mardiono, D. (2014). Pengaruh motivasi dan Disiplin Kerja terhadap Kepuasan kerja karyawan. Jurnal Ilmu \& Riset Manajemen, 3(3).

Martoyo, S. (2007). Manajemen Sumber Daya Manusia. Yogyakarta: BPFE.

Muslih, B. (2012). Analisis pengaruh motivasi terhadap kepuasan kerja dan kinerja pegawai di PT Sang Hyang Seri (Persero) regional III Malang. Jurnal Aplikasi Manajemen, 10(4), 799-810.

Paramita, W., Prayuda, W. H., \& Handaru, A. W. (2013). Pengaruh lingkungan kerja dan budaya organisasi terhadap kepuasan kerja karyawan pada bank btn (persero) cabang Bekasi. JRMSI-Jurnal Riset Manajemen Sains Indonesia, 4(2), 257275.

Prastowo, I. (2015). Pengaruh pengembangan karir, lingkungan kerja dan komitmen organisasi terhadap kepuasan kerja pegawai Hotel Sahid Jaya Solo dengan keyakinan diri (SELF EFFISASI) sebagai variabel pemoderasi. Jurnal Sainstech, 1(3). 
Priadana, S., \& Riswandi, I. (2013). Pengaruh Kemampuan Kerja Dan Motivasi Terhadap Kepuasan Kerja Serta Implikasinya Pada Kinerja Pegawai Dinas Pertambangan Dan Energi Provinsi Jawa Barat. Jurnal Ekonomi, Bisnis $\mathcal{E}$ Entrepreneurship, 7(2), 52-63.

Riansari, T., \& Sudiro, A. (2012). Pengaruh kompensasi dan lingkungan kerja terhadap kepuasan kerja dan kinerja karyawan (Studi Kasus PT Bank TabunganPensiunan Nasional, TbkCabang Malang). Jurnal Aplikasi Manajemen, 10(4), 811-820.

Rozzaid, Y., Herlambang, T., \& Devi, A. M. (2015). Pengaruh kompensasi dan motivasi terhadap kepuasan kerja karyawan. Jurnal Manajemen Dan Bisnis Indonesia, 1(2).

Saleem, R., Mahmood, A., \& Mahmood, A. (2010). Effect of work motivation on job satisfaction in mobile telecommunication service organizations of Pakistan. International Journal of Business and Management, 5(11), 213.

Salunke, G. (2015). Work Environment and its effect on job satisfaction in cooperative sugar factories in Maharashtra, India. Abhinav International Monthly Refereed Journal of Research in Management \& Technology, 4(5), 21-31.

Sedarmayanti, M. P. (2009). Sumberdaya Manusia dan Produktivitas Kerja Karyawan. Bandung, Refika Aditama.

Sudiarditha, I. K. R., Waspodo, A. A. W. S., \& Triani, N. A. (2016). Pengaruh lingkungan kerja dan motivasi kerja terhadap kepuasan kerja karyawan pada direktorat umum lembaga pelayanan publik televisi republik Indonesia. Jurnal Manajemen, 20(2), 278-292.

Sule, E. T., \& Saefullah, K. (2005). Pengantar manajemen. Prenada Media.

Susetyo, W. E., Kusmaningtyas, A., \& Tjahjono, H. (2014). Pengaruh budaya organisasi dan lingkungan kerja terhadap kepuasan kerja dan kinerja karyawan pada pt. bank muamalat indonesia divisi konsumer area cabang Surabaya. JMM17 Jurnal Ilmu Ekonomi \& Manajemen, 1(1), 83-93.

Tampubolon, S. M. (2010). Pengaruh Gaya Kepemimpinan, Lingkungan Kerja, Dan Harapan Dosen Terhadap Kepuasan Kerja. Jurnal Manajemen Pendidikan, 1(2), 111-119. 